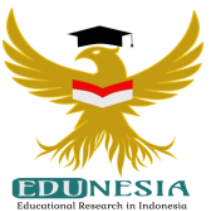

\title{
Online Learning with Google Forms Included with Youtube and Link Material
}

\author{
Masnurul Sholihah \\ Biology Education, SMPN 4 Danau Panggang, Indonesia. \\ Corresponding Email: masnurlsholihah@gmail.com, Phone Number: 0822 xxxx xxxx
}

\author{
Article History: \\ Received: Apr 24, 2021 \\ Revised: May 30, 2021 \\ Accepted: Jun 01, 2021 \\ Online First: Jun 02, 2021
}

\section{Keywords:}

Link Material, Google Form,

Online Learning, youtube.

\section{Kata Kunci:}

Link Materi, Google Form, Pembelajaran Daring, Youtube.

\footnotetext{
How to cite:

Sholihah, M. (2021). Online Learning with Google Forms Included with Youtube and Link Material. Edunesia: Jurnal Ilmiah Pendidikan, 2 (2): 551556.

This is an open access article under the $\mathrm{CC}-\mathrm{BY}-\mathrm{NC}-\mathrm{ND}$ license

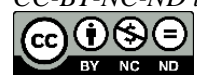

\begin{abstract}
The increasing number of people infected with the corona virus causes the disruption of the face-to-face learning process directly, because it can cause the emergence of new corona virus clusters in schools. As a substitute is the implementation of an Online learning system. The purpose of this research is to improve student learning outcomes in online learning using a combination, google form, youtube and material links. This research method is in the form of data collection on the value of student learning outcomes that are analyzed in a descriptive and classical manner using a formula to find the presentation of student learning outcomes. The benefit of this research is that it can be used as a reference for exploring the concept of Google Forms, Youtube and Link Material in online learning. The results of this study indicate that online learning using a combination of google form, youtube and material links can improve learning motivation, learning activities and improve student learning outcomes.
\end{abstract}

Abstrak: Semakin bertambahnya orang yang terinfeksi virus corona menyebabkan terhambatnya proses pembelajaran tatap muka secara langsung, karena dapat menyebabkan timbulnya kluster baru virus corona di sekolah-sekolah. Sebagai gantinya adalah dilaksanakannya system pembelajaran Daring. Tujuan penelitian ini adalah untuk meningkatkan hasil belajar siswa dalam pembelajaran daring menggunakan kombinasi, google form, youtube dan link materi. Metode penenelitian ini berupa pengambilan data nilai hasil belajar siswa yang analsis secara Diskriptif Kompratif secara klasikal mengunakan rumus untuk mencari presentasi hasil belajar siswa. Manfaat dari penelitian ini antara lain adalah dapat digunakan sebagai salah satu acuan untuk mendalami konsep tentang Google Form, Youtube dan Link Materi"dalam pembelajaran daring. Hasil penelitian ini menunjukkan bahwa Pembelajaran Daring menggunakan kombinasi google form, youtube dan link materi dapat memperbaiki motivasi belajar, aktivitas belajar dan meningkatkan hasil belajar siswa. 


\section{A. Introduction}

The increasing number of people infected with the corona virus causes disruption of the face-to-face learning process directly, because it can lead to the emergence of new virus clusters in schools. As a substitute is the implementation of an Online learning system (Gormsen \& Koijen, 2020; Hiscout et al, 2020).

The times are getting modern. Information technology is also growing rapidly and increasingly penetrating almost every aspect of community life. Various fields began to be involved in technology incubators such as business, industry, agriculture, health, and without exception education. In the field of education, information technology has been used to support services for administration, the learning process, re-registration, libraries, access to values, quick and easy reference searches, research processes, tuition payments, even for selection of new admissions, including online learning.

Online learning is learning using an internet-based interactive model and a Learning Management System (Asmuni, 2020; Sadikin \& Hamidah, 2020). Online learning is a program for organizing online learning classes to reach a massive and broad target group (Ernawati, 2020). Online learning is part of distance education that specifically combines electronic technology with internet-based technology (Yuangga \& Sunarsi, 2020). Online learning must be carried out by adhering to the principles of being open, independent learning, thorough learning, using information and communication technology, using other educational technologies and / or integrated learning. This online learning is one of the solutions for educational institutions so that the teaching and learning process continues amid the Covid-19 pandemic (Arizona, 2020; Anugrahana, 2020). Teachers can still teach and students still have their rights to learn.

To provoke student interest, a teacher must be good at being creative in online learning. For example online learning that combines google form, youtube and material links, so that it creates high interest from within students to learn. Interest can be interpreted as a feeling of preference, a sense of interest in something or an activity (Kartika et al, 2020). Interest as a constant tendency to pay attention continuously accompanied by a sense of pleasure (Siagian, 2015). Learning interest is basically the acceptance of a relationship between oneself and outside oneself. Students who are interested in learning will receive the material that has been delivered by their teacher and look for various lesson literature without coercion from anyone. Interest is a feeling of preference and attachment to something or activity without being asked. This statement identifies that the person who is interested will be attracted. Interested in this is a form of feeling happy in something. From the explanation above, it can be concluded that interest in learning is a person's desire to carry out learning activities that are born without coercion accompanied by a sense of attention, interest, and pleasure in carrying out these activities. Interest is characterized by preference, interest or pleasure as a form of expression of something that is of interest.

\section{B. Method}

This research procedure consisted of 2 cycles, each of which consisted of an online package of Online Learning with Google Forms Embedded with Youtube and Link Material.

In this study, the instrument used for data collection was the value of learning outcomes. Data analysis carried out after application of Online Learning with Google Forms Embedded with Youtube and Link Materials, namely; 
a. To determine student achievement, a descriptive comparative analysis was used. Where to find the percentage of student learning completeness classically using the following formula:

$$
\%=\frac{\mathrm{n}}{\mathrm{N}} \times 100
$$

Note:

$\mathrm{n}=$ The number of students who scored $\geq 55$

$\mathrm{N}=$ Total number of students criteria

Value $<55=$ students did not complete their studies

Value $\geq 55$ = students complete their studies

Learning outcomes are said to be successful if they meet the completeness percentage $\geq 55 \%$.

b. Calculate the class average value with the formula:

$$
\overline{\mathrm{X}}=\frac{\sum X}{N}
$$

Note:

$X=$ average (mean)

$\sum \mathrm{X}=$ sum of all scores

$\mathrm{N}=$ number of subjects

(Sudjana, 2014).

Samples were taken from class IX of SMPN 1 Danau Panggang, The number of students in the sample was 21 people with details of 10 males and 11 females.

This research method uses data retrieval instruments in the form of student learning outcomes which are analyzed in a classical descriptive manner using certain formulas as listed above to find a presentation of student learning outcomes. Learning outcomes are concluded successful if the presentation of learning outcomes completeness reaches $\geq 55 \%$.

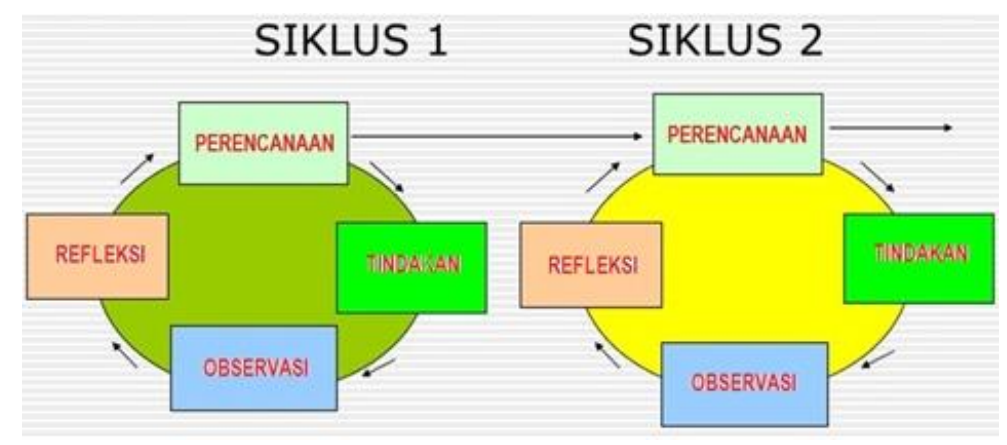

Figure 1. Action research

\section{Result and Discussion}

From several tables and charts the summary of the research results below, starting from the pre-cycle, action cycle I, cycle II and up to cycle III action. Tables and graphs consist of a summary table listing student learning outcomes, a summary of the results of student activity observations, a summary of the results of observations of teacher activities and a summary of measuring learning outcomes, teacher and student activities. 
Table 1. The value of student learning outcomes

\begin{tabular}{cccc}
\hline Category & $\begin{array}{c}\text { Pre-cycle } \\
\text { Value }\end{array}$ & $\begin{array}{c}\text { Cycle I } \\
\text { Value }\end{array}$ & $\begin{array}{c}\text { Cycle II } \\
\text { Value }\end{array}$ \\
\hline Average & 54,67 & 72,31 & 73,64 \\
Completeness & $53,33 \%$ & $92,31 \%$ & $90,91 \%$ \\
\hline
\end{tabular}

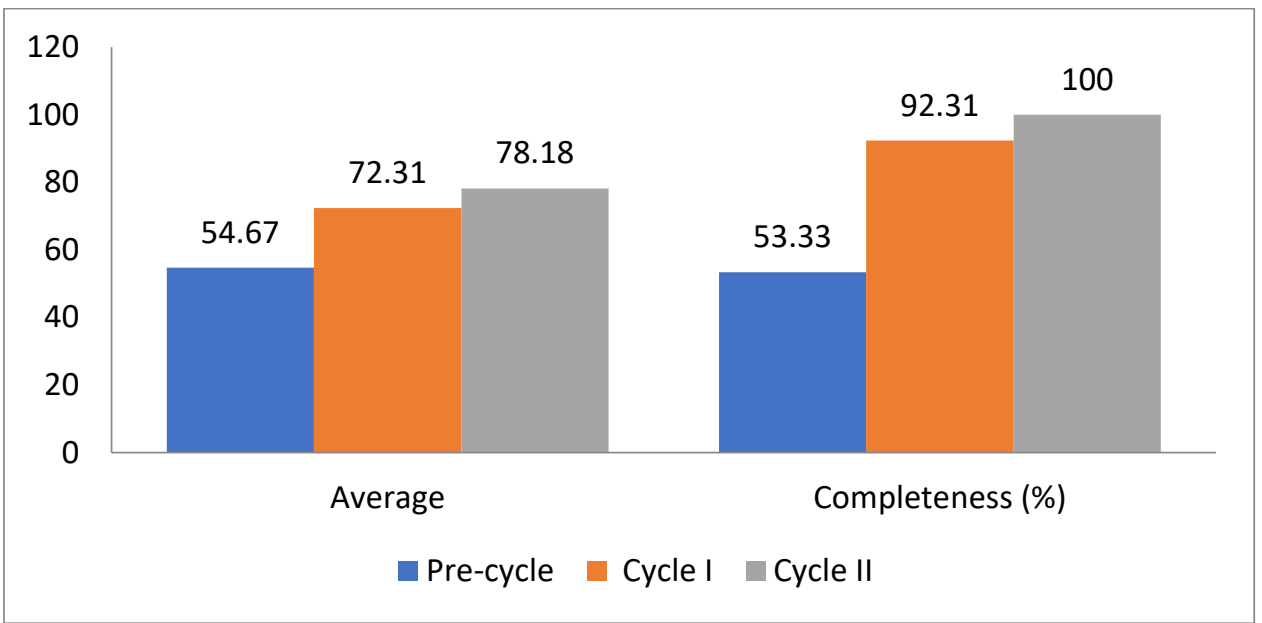

Figure 2. Histogram of student learning outcomes

In the initial conditions the average value is 54.67 to 72.31 in the first cycle, to 78.18 in the second cycle. Everything is calculated based on the scores obtained by students from the lowest to the highest.

The lowest value of the pre-cycle condition was 20, at the end of the cycle the lowest value increased to 60 . Meanwhile, the highest value also occurred for a decrease from the pre-cycle condition, which was 100 in the final cycle of 80, but all of them were complete. Students who have completed increase from the pre-cycle condition to only 8 people, there is a final cycle, all of them are complete.

The results of this study indicate that online learning with Google Form embedded with YouTube and material links can improve learning motivation, learning activities and improve student learning outcomes. In this combination contains directly the multiple representation learning model. Multiple representations. Multiple representation is a way in which students express concepts in various forms (Yusup, 2011). Multiple representations have 4 types of representations, namely verbal representations, image representations, physical representations, and mathematical representations (Leigh, 2014).

In a study on a science clump by Doyan et al. (2018) with the ANOVA test it was concluded that there was an effect of multiple representational learning approaches and student learning motivation on learning outcomes. Multi representation is one way to increase external motivation.

In a study on multiple representations by Widianingtiyasa, et al (2015), it was shown that students in the experimental class showed an increase in learning outcomes by $7.14 \%$ in posttests. While students in the control class experienced an increase of $0.32 \%$. Thus it can be seen that the increase in learning outcomes is greater in the experimental class so that it can be concluded that the multi-representation approach has a positive influence on students' cognitive abilities. 
Mousavi and Sweller (1995) examined the reduction of cognitive content by blending audio and visual presentation models. The results showed that various sources of information produce a large cognitive content, effective cognitive capacity can be increased when used audio and visuals.

The form of using audio and visual in this research is that students use the YouTube application in learning the material. Inside the YouTube application, there are animations in the form of words, images and videos that can help students construct or build their knowledge to obtain higher learning outcomes.

This is also explained by Mayer and Moreno (2012), a person who examines animation instruction in teaching that can help students build relationships between words and images in multimedia learning, where the results show that students who get narrative explanations along with animation have higher scores. than students who are given narration or amination only.

\section{Conclusion}

Online Learning with Google Forms Embedded with Youtube and Material Links can improve student biology learning outcomes in the online learning process system during the Covid19 epidemic as it is today.

\section{References.}

Anugrahana, A. (2020). Hambatan, Solusi dan Harapan: Pembelajaran Daring Selama Masa Pandemi Covid-19 Oleh Guru Sekolah Dasar. Scholaria: Jurnal Pendidikan dan Kebudayaan, 10(3), 282-289.

Arizona, K., Abidin, Z., \& Rumansyah, R. (2020). Pembelajaran Online Berbasis Proyek Salah Satu Solusi Kegiatan Belajar Mengajar Di Tengah Pandemi Covid-19. Jurnal Ilmiah Profesi Pendidikan, 5(1), 64-70.

Asmuni, A. (2020). Problematika Pembelajaran Daring di Masa Pandemi Covid-19 dan Solusi Pemecahannya. Jurnal Paedagogy, 7(4), 281-288.

Doyan, A., Taufik, M., \& Anjani, R. (2018). Pengaruh pendekatan multi representasi terhadap hasil belajar fisika ditinjau dari motivasi belajar peserta didik. Jurnal Penelitian Pendidikan IPA, 4(1).

Ernawati, Y. (2020). Problematik Pembelajaran Daring Mata Kuliah Bahasa Indonesia. Jurnal Ilmiah Bina Edukasi, 13(1), 01-15.

Kartika, S., Husni, H., \& Millah, S. (2019). Pengaruh Kualitas Sarana Dan Prasarana Terhadap Minat Belajar Siswa Dalam Pembelajaran Pendidikan Agama Islam. Jurnal Penelitian Pendidikan Islam,[SL], 7(1), 113-126.

Gormsen, N. J., \& Koijen, R. S. (2020). Coronavirus: Impact on stock prices and growth expectations. The Review of Asset Pricing Studies, 10(4), 574-597. 
Hiscott, J., Alexandridi, M., Muscolini, M., Tassone, E., Palermo, E., Soultsioti, M., \& Zevini, A. (2020). The global impact of the coronavirus pandemic. Cytokine $\mathcal{E}$ growth factor reviews, 53, 1-9.

Leigh, G. (2004). Developing multi-representational problem solving skills in large, mixed-ability physics classes (Master's thesis, University of Cape Town).

Mayer, R. E. \& Moreno, R. (2002). Animation as an aid to multimedia learning. Educational Psychology Review, 14,87-99.

Mousavi, S., Low, R., Sweller, J. (1995). Reducing Cognitive Load by Mixing Auditory And Visual Presentation Modes. Jurnal of Psychology. Volume 87-No. 2.

Sadikin, A., \& Hamidah, A. (2020). Pembelajaran Daring di Tengah Wabah Covid-19:(Online Learning in the Middle of the Covid-19 Pandemic). Biodik, 6(2), 214-224.

Siagian, R. E. F. (2015). Pengaruh minat dan kebiasaan belajar siswa terhadap prestasi belajar matematika. Formatif: Jurnal Ilmiah Pendidikan MIPA, 2(2).

Sudjana, N. (2014). Penilaian Hasil Proses Belajar Mengajar. Bandung: $\quad$ PT Remaja Rosdakarya.

Widianingtiyas, L., Siswoyo, S., \& Bakri, F. (2015). Pengaruh pendekatan multi representasi dalam pembelajaran fisika terhadap kemampuan kognitif siswa SMA. Jurnal Penelitian E Pengembangan Pendidikan Fisika, 1(1), 31-38.

Yuangga, K. D., \& Sunarsi, D. (2020). Pengembangan media dan strategi pembelajaran untuk mengatasi permasalahan pembelajaran jarak jauh di pandemi covid-19. JGK (Jurnal Guru Kita), 4(3), 51-58.

Yusup, M. (2009). Multirepresentasi dalam Pembelajaran Fisika. Makalah disajikan dalam Seminar Nasional Pendidikan, di Universitas Sriwijaya. 